mental evidence presented here demonstrating the ciliotoxic effect in the chicken tracheal organ culture system of three out of the four mucolytic agents tested.

\section{CONCLUSION}

Two nasal decongestants and four mucolytic algents were tested on the cilia of chicken tracheal organ cultures. Of all drugs tested only pancreatic domase showed no ciliotoxicity. In the light of these results the use of the two nasal decongestants should be discouraged until further toxicity studies can be carried out in organ culture systems or in vivo. If the use of a mucolytic agents is felt to be necessary, pancreatic dornase should be the drug of choice.

\section{REFERENCES ANI NOTES}

1. Carson, S., Goldhamer, R., and Carpenter. R.: Mucous transport in the respiratory tract. Amer. Rev. Resp. Dis., 93: 86 (1966)

2. Cherry, J. D., Roden, V. J., and Rejent, A. J.: The inhibition of ciliary activity in tracheal organ cultures by sera from children with cystic fibrosis and control subjects. J. Pediat., 79: 937 (1971).

3. Cherry, J. D., and Taylor-Robinson, D.: Large quantity production of chicken embryo tracheal organ cultures and use in virus and mycoplasma studies. Appl. Microbiol., 19:658 (1970).

4. Cherry, J. D., and Taylor-Robinson, D.: Growth and pathogenesis of Mreoplasma mycoides var. capri in chicken embryo tracheal organ cultures. Infect. Immunity, 2: 431 (197(1).
5. Cheung. A. T. W., and Jahn. T. L.: Determination of the beat pattern of tracheal cilia. Pediat. Res., l(1: 140) (1976).

6. Dalhamn, T.: Mucous flow and ciliary activity in the trachea of healthy rats and rats exposed to respiratory irritant gases. Acta Physiol. Scand. Suppl., $123(1956)$.

7. Kimura, E. I': Effects of chemical agents on ciliated tracheal epithelium. Arch. Otolaryngol., 69: 674 (1959).

8. Krahl, V. E., and Bulmash, M. H.: Studies on living ciliated epithelium. Amer. Rev. Resp. Dis., 99: 711 (1969).

9. Laurenzi, G. A.. Collins, B.. and Grearner, J. J.: Mlucous flow in the mammalian tracheal. Proceedings of the Tenth Aspen Emphysema Conference, pp. 27-41) (United States Public Health Service Publication no. 1787, $1967)$.

10. Licherman, J.: Measurement of sputum viscosity in cone-plate viscometer. Amer. Rev. Resp. Dis., 97: 662 (1968)

11. Lierle, D. M., and Moore, P. M.: Fffects of drugs on ciliary activity of mucosa of upper respiratory tract. Arch. Otolaryngol., 19: 55 (1934).

12. Proetz, A. W.: Effects of certain drugs upon living ciliated epithelium. J. Laryngol. Otolaryngol., 49: 557 (1934).

13. Rylander. R.: Current techniques to measure alterations in the ciliary activity of intact respiratory epithelium. Amer. Rev. Resp. Dis., 9.3: 67 (1966).

14. Taussig, L.: Mlists and aerosols: New studies and new thoughts. J. Pediat, 84: $619(1974)$.

15. We wish to acknowledge the assistance of Stephanic Biggs.

16. This research was presented in part at the Cystic Fibrosis Club Meeting, April 27, 1976 .

17. Requests for reprints should be addressed to: J. D. Cherry, M.D., Department of Pediatrics. University of California at Los Angeles, Los Angeles. Calif. 90024 (USA).

18. Received for publication October 21.1970.

19. Accepted for publication January 19, 1977.
Enterocolitis milk leukocytes mononuclear phagocytes neonate phagocytosis

\title{
Protection against Experimental Necrotizing Enterocolitis by Maternal Milk. I. Role of Milk Leukocytes
}

\author{
JANE PITT! (31) BARBARA BARLOW, AND WILLIAM C. HEIRD \\ Deparments of Pediatrics and Surgery, College of Physicians and Surgeons, Columbia University, \\ New York, New York, USA
}

\section{Summary}

A rat model of necrotizing enterocolitis of the neonate in which maternal milk had been protective was studied to determine what components of the milk afforded protection and by what mechanism. Frozen and thawed rat milk was not protective, but formula supplemented with rat milk cells was. It was concluded that the cells provided protection. The cells, which are principally mononuclear phagocytes, can phagocytize and kill the Klebsiella pneumoniae strain used in the animal model. Animals with necrotizing enterolitis had peritonitis and bacteremia caused by this bacillus.

\section{Speculation}

Milk mononuclear phagocytes may protect the neonatal rat from enterocolitis by their antibacterial and wound-healing activities or by their ability to enhance the neonatal immune response. The etiologic role of bacteria in this disease, not proven in these experiments, must be determined by experiments in germfree rats.

Breast milk affords the neonatal animal protection against microbial infections $(6-8,14)$. Specific immunity has been attributed to antibodies (13). Additionally, antimicrobial activity of milk has been shown to reside in lactoferrin, Escherichia coli, lysozyme, and lactoperoxidase. Lactoferrin is bacteriostatic against $E$. coli (5) and Candida albicans (10), lysozyme is bactericidal against certain gram-positive organisms and may enhance complement-mediated bacterialysis of gram-negative bacteria (9), and lactoperoxidase is found in milk with hydrogen peroxide and halide and can kill bacteria (11). In addition, the high lactose, low protein, and low phosphate content of milk provides a poorly buffered medium which may discourage outgrowth of certain microorganisms. 
We have previously reported that in a model of enterocolitis induced in newborn Sprague-Dawley rats, maternal milk was found to be protective. A nutritionally similar artificial formula failed to protect the rats which developed neonatal necrotizing enterocolitis and had high levels of fecal Klebsiella and positive peritoneal and/or blood cultures (2). This model provided an opportunity to analyze the protective components of milk. They were tested for their in vivo protective activity and the kinetics of their bactericidal activity was studied in vitro.

\section{MATERIALS AND METHODS}

The strain of $K$. pncumoniae used in these experiments was isolated originally from the normal flora of an infant in the intestive care nursery. It was a rough, serum-sensitive strain. The organism was stored on Trypticase soy agar (TSA) (24) and was prepared by inoculation of 10 ce Trypticase soy broth (TSB) (24) with three colonies of the Klebsiclla and incubation in a shaking waterbath overnight at $37^{\circ}$. Appropriate dilutions of the overnight culture were used as inocula in the various experiments; they were measured by colony counts of serial 10 -fold dilutions on TSA which were read after $24 \mathrm{hr}$.

\section{ANIMAL EXPERIMENTS}

Only litters of Sprague-Dawley rats (25) whose births were witnessed were used, because they could be removed from their mothers before feeding. Generally, in each litter, five of these newborn rats were removed from their mother to be fostered by a nonlactating female rat. The fostering promoted gastric and bladder emptying and provided warmth (15). The remaining rats were left in their mother and used as controls in feeding protocol. The fostered rats were hand fed by various defined diets: two of the five in each group received artificial formula to serve as additional controls, because this group uniformly developed neonatal necrotizing enterocolitis in our previous study (2).

\section{EXPERIMENTAL PROTOCOL}

Necrotizing enterocolitis was produced in the formula-fed rats as previously described (2). Briefly, all animals were exposed to daily hypoxia by placement in a plastic bag for 3-5 min until their mucous membranes were cyanotic. They were colonized by $2-5 \times 10^{\times} \mathrm{K}$. pneumoniac organisms by oral feeding each day. Such colonization was previously shown to be unnecessary for production of the disease (2), but use of a known organism as a marker allowed for more precise evaluation of the pathogenesis of the discase.

\section{FEEDING PROTOCOLS}

Artificial Formula. The artificial formula was made of $15 \mathrm{~g}$ Similac PM 60/40 (26) made up to a final volume of $75 \mathrm{ml}$ with liquid EsBILAC (27). Rats fed this formula maintained near normal growth rates for 1 week (2). The formula was prepared aseptically and stored at $-20^{\circ}$.

Frozen Rat Milk. Frozen rat milk was obtained by manual expression from lactating rats separated from their young for 6$12 \mathrm{hr}$ and treated with 2 units oxytocin i.p. (28). Two to $5 \mathrm{ml}$ milk were regularly obtained by this technique. The milk was stored at $-20^{\circ}$ for no more than $36 \mathrm{hr}$.

\section{LEUKOCYTE PREPARATIONS}

Leukocyte preparations were handled with plastic or siliconized glass pipettes and tubes to prevent loss of cells by adhesion.

Rat Milk Leukocytes. These were isolated by differential centrifugation. Milk was obtained either by manual expression of lactating rats as above, or by collection of the gastric contents of week-old rats just after feeding. In the latter case the soft milk clot was dispersed in 10 volumes Hanks' basic salt solution (HBSS), mixed, strained through 115 -guage mesh, and centri- fuged at $400 \times g$. After the cream layer was removed, the supernatant was decanted and the pellet resuspended in 10 volumes HBSS and the washing was repeated. The method for manual expression of milk was essentially the same except that dispersion by strainer and vortexing were omitted.

Rat Peritoneal Lenkocytes. These were harvested from adult rats killed by ether anesthesia 4 days after an intraperitoneal injection of 20 ce sterile $1.5 \%$ sodium caseinate in $0.9 \%$ saline solution (24). The peritoneum was washed with 20 ce HBSS and the abdomen massaged. The peritoneal cavity was opened and the washings aspirated, centrifuged at $200 \times \mathrm{g}$, and handled as the blood leukocytes below.

Rat Blood Lenkocytes. Rat blood leukocytes were obtained from whole blood collected by cardiac puncture of ether anesthetized adult rats. The blood was collected in a heparinized syringe to which 0.5 volume $5 \% \quad 250,000$ molecular weight dextran (29) in normal saline was added. The blood was allowed to sediment at $1 \mathrm{G}$ at room temperature for $20 \mathrm{~min}$. The leukocyte-rich supernatant was removed and entrifuged at 200 $\mathrm{G}$ at room temperature for $5 \mathrm{~min}$, and washed twice with HBSS.

All of the leukocyte preparations were adjusted to a concentration of $10^{7}$ leukocytes/ce in HBSS by counting the cells in a Neubauer counting chamber and then suitably diluting for use in the experiments. Smears stained by Wright's solution were prepared for differential counts.

\section{IN VITRO STUDIES OF LEUKOCYTE FUNCTION}

One-tenth milliliter of the various leukocyte preparations was added to $0.8 \mathrm{ml}$ of previously frozen rat milk or formula brought to room temperature. To this mixture $0.1 \mathrm{ml}$ of the overnight culture of Klebsiclla adjusted to a concentration of $0.9-2 \times 10^{8} /$ $\mathrm{ml}$ was added. The appropriate concentration was selected by the turbidity of a $1: 10$ dilution of the culture which had been adjusted to OD 100 on a Klett colorimeter at $600 \mathrm{~mm}$. The actual bacterial count was determined by plating of serial 10 -fold dilutions of the inoculum on blood agar. Since log phase cultures planted on EMB or MacConkey agar usually had a plating efficiency of $50-70 \%$ of that on blood agar and since growth was possible during the subsequent incubations and thus the organism might be in log phase, blood agar was used for all the viable counts.

The number of bacteria in these mixtures was determined by plating of serial dilutions of the inoculum on blood agar. The mixtures were placed in $12 \times 75 \mathrm{~mm}$ polypropylene tubes $(30)$ and incubated in a $37^{\circ}$ warm room on a rotator (31) at $12 \mathrm{RPM}$. One-tenth-milliliter samples of the mixtures were taken at 1,2, and $t h r$ and the number of viable bacteria determined. The serial 10 -fold dilutions were made in sterile distilled water and leukocytes disrupted by vortexing the samples for 60 sec. In subsequent experiments determination of the adequacy of this method resolved that more complete disruption of cells was achieved by $10 \mathrm{sec}$ of ultrasonication of the cells. This treatment did not lower the colony count of a suspension of Klebsiclla. After $2 \mathrm{hr}$ of incubation. slides were prepared and stained with $1 \%$ methylene blue in order to enumerate intracellular and extracellular bacteria.

\section{IN VIVO STUDIES OF LEUKOCYTE FUNCTIONS}

Newborn rats, given an oral dose of $2-5 \times 10^{7} \mathrm{Klebsiella}$ suspended in $0.05 \mathrm{ml}$ HBSS were either breastfed by their mothers or received food by nasogatstric silicone catheter (32) $0.76 \mathrm{~mm}$ in diameter cut down to $2 \mathrm{~cm}$ length and attached to a 1 ce tuberculin syringe.

\section{STATISTICAL METHODS}

Because of the small size of some of the samples, $P$ values were determined directly by the Fisher exact test. 


\section{RESULTS}

\section{ANIMAL EXPERIMENTS}

In order to determine the components of rat milk that afforded protection to the newborn animal, litters were split in three groups: some fed normally (positive control), some by artificial formula (negative control), and some by the experimental mixture. It was determined that frozen rat milk was not protective (90\% mortality). When milk leukecytes were added to the frozen preparation all of five rats were protected. Four of 5 were protected when peritoneal cells were added to frozen milk, and 21 of 26 were protected when leukocytes of various sources were added to formula. The results of these experiments are summarized in Table 1.

\section{IN VITRO STUDIES}

Frozen rat milk was bacteriostatic to the test Klebsiella organism. The formula supported growth of the bacterium. Leukocytes from various sources with formula or frozen rat milk resulted in killing of the bacterium (Fig. 1). The bactericidal

Table 1. Feeding and necrotizing enterocolitis (NEC) mortality

\begin{tabular}{|c|c|c|}
\hline \multirow[b]{2}{*}{ Feeding } & \multicolumn{2}{|c|}{ NEC mortality } \\
\hline & $\begin{array}{c}\text { Dead/ } \\
\text { total }\end{array}$ & $P$ \\
\hline Fresh rat milk & $0 / 40$ & \\
\hline Frozen rat milk & $9 / 10$ & \\
\hline Frozen rat milk + milk leukocytes & $0 / 5$ & $<0.002^{\prime}$ \\
\hline Frozen rat milk + peritoneal leukocytes & $1 / 5$ & $<0.02^{1}$ \\
\hline Formula & $30 / 30$ & \\
\hline Formula + milk leukocytes & $1 / 5$ & $<0.0\left(01^{2}\right.$ \\
\hline Formula + peritoneal leukocytes & $2 / 11$ & $<0.001^{2}$ \\
\hline Formula + blood leukocytes & $2 / 10$ & $<0.0(0)^{2}$ \\
\hline
\end{tabular}

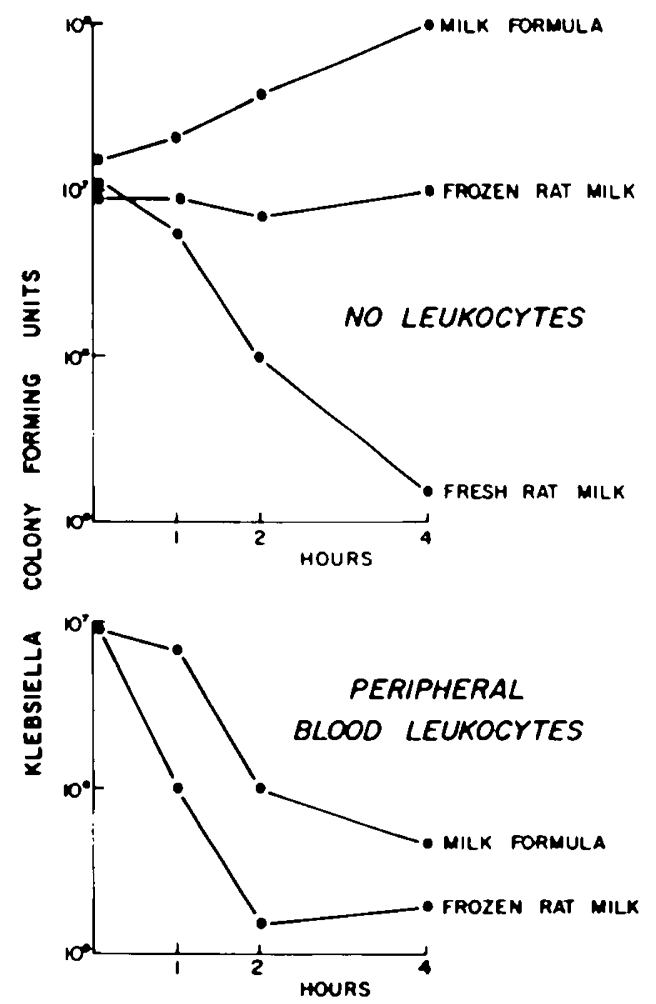

activity was not observed in stationary tubes; thus it appeared that killing required tumbling of the incubating tubes. In all the smears of 2-hr incubations examined, however, less than $50 \%$ of the bacteria were cell associated, suggesting that killing was partially extracellular but was apparently stimulated by the aeration and/or leukocyte-particle contact caused by rotation of the incubation tubes (Table 2).

The cellular composition of the population of leukocytes is listed in Table 3. Mononuclear phagocytes were differentiated from lymphocytes by their phagocytic uptake of $0.1 \%$ neutral red. In contrast, dead cells took up stain in a diffuse fashion.

Milk leukocytes were obtained from the stomach and upper gut of rats up to 6 days of age (20) and observed under phase contract microscopy after 30 min of incubation with $0.1 \%$ neutral red. During the initial 10-15 min the dye remained localized in phagosomes but subsequently, while still under direct visualization, the stain became diffuse, indicating death of the cell.

\section{DISCUSSION}

In neonatal rat enterocolitis the protective action of rat milk appears to depend largely on the leukocytes. This can be concluded from the observations that frozen and thawed milk failed to be protective and that its protective activity could be restored by leukocytes from various sources.

The possibility that it is the bactericidal activity of the leukocytes that protects is raised by the bactericidal activity of the various milk-leukocyte mixtures. Bacterial killing is not exclusively intracellular, but seems to require motion of the incubation mixture, suggesting a dependence on acration, leukocyteparticle contact, or both. The phagocytosed particles may be bacteria or fat droplets. Liposome contents may be oxidized into bactericidal aldehydes. The peritoneal and blood phagocytes incorporate lipid droplets during incubation; milk leukocytes washed of milk and maintained in tissue culture lose these refractile inclusions (17).

In general, the leukocytes were more actively bactericidal in rat milk than in formula. The reason for this has not been evaluated, but does not appear to depend on enhancement of
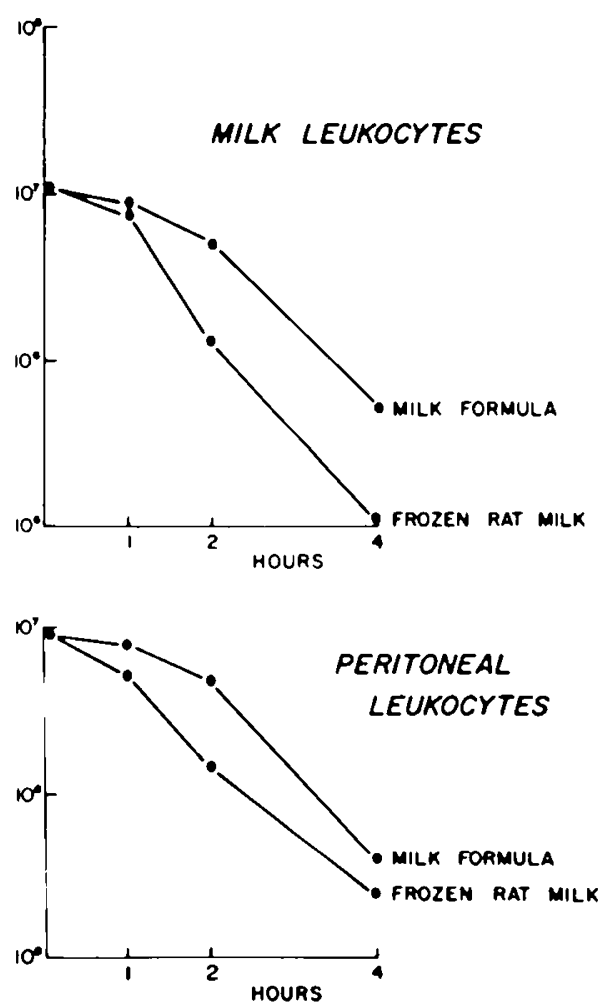

Fig. 1. Ability of milk preparations with and without leukocytes to kill Klebsiella. Each point represents the mean of two experiments with triplicate samples. The four graphs represent killing curves of preparations of varying milks with either no added leukocytes (upper left quadrant) or leukocytes of the variety labeled. The composition of these cell populations is listed in Table 3. 
Table 2. Percentage of cell-associated Klebsiella after 2 hr of incubation (200 bacteria counted)

\begin{tabular}{ll}
\hline Milk leukocytes and frozen rat milk & $26 \pm 8$ \\
Peripheral blood leukocytes and formula & $22 \pm 12$ \\
Peritoneal leukocytes and formula & $27 \pm 5$ \\
Peritoneal leukocytes and frozen rat milk & $32 \pm 7$ \\
\hline
\end{tabular}

Table 3. Composition of cell populations ${ }^{1}$

\begin{tabular}{lccc}
\hline & $\begin{array}{c}\text { Mononu- } \\
\text { clear phago- } \\
\text { cytes }\end{array}$ & $\begin{array}{c}\text { Polymorpho- } \\
\text { nuclear } \\
\text { phagocytes }\end{array}$ & $\begin{array}{c}\text { Lympho- } \\
\text { cytes }\end{array}$ \\
\hline $\begin{array}{l}\text { Milk leukocytes } \\
\begin{array}{l}\text { Peripheral blood } \\
\text { leukocytes }\end{array}\end{array}$ & $80-92$ & $1-10$ & $5-16$ \\
Peritoneal leukocytes & $6-13$ & $71-87$ & $7-17$ \\
\hline
\end{tabular}

${ }^{1}$ One hundred cells were counted in eight samples of each preparation.

phagocytosis by opsonins in milk, because not all the killed bacteria are phagocytosed.

At least some of the leukocytes ingested remain viable in the upper gastrointestinal tract of the rat up to 1 week. It is possible that they continue to be active at that site.

It should be noted further that the bactericidal activity of these cells appeared greater than that of monocytes previously studied by others (19). This cannot be attributed to any uniqueness of milk mononuclear phagocytes because peritoneal mononuclear phagocytes in milk were also very active. The enhanced activity may however be due to species differences, or to uniqueness of the suspending medium. The latter could encompass such possibilities as the "curdy" nature of milk supporting surface phagocytosis (23), the high content of unsaturated fatty acids providing substrate for oxidative production of malonyaldehyde (21), the triglycerides enhancing monocytic phagocytosis (22), or of the synthesis by these cells of complement components (16).

These studies do, however, offer evidence that leukocytes in milk provide passive protection at the gut barrier against systemic bacterial invasion. Other investigators have documented the role of milk leukocytes in the passive transfer of allogeneic sensitivity (3). Our experiments suggest that in the gut, the monocytic phagocytes in milk mediate protection against enterocolitis and sepsis. Immunologic competence, transferred to neonatal animals by passive transfer of adult mononuclear phagocytes $(1,4)$, may have a natural counterpart in milk feedings.

These results are consistent with a postulated pathogenetic role for bacteria in neonatal enterocolitis and a bactericidal mechanism of protection by leukocytes from this disorder. Neither of these hypotheses has been proven. Previous (2) and subsequent studies indicate that the disease can develop without intentional colonization but is always accompanied by gramnegative enteric overgrowth in the intestine. Studies are underway in germfree rats to determine the role of bacteria in this disease. The mononuclear phagocyte has been shown to have a role in wound healing (12). This could provide an alternative mechanism of protection by these cells. Unpublished studies (18) provide evidence that the leukocytes modify the enteric flora both under normal conditions and those of hypoxia but do not rule out the possibility that there are more indirect effects of the cells on the resident bacteria.

These findings cannot be directly extrapolated to man. The newborn rat is immunologically far more immature than the newborn infant. Furthermore, at least in regard to humoral immunity, the rat is more dependent on milk feeding than is man. Ingested antibodies and other proteins are readily found in the systemic circulation of the suckling rat, a condition not seen in man. Therefore, careful prospective studies in man will be required to determine whether these observations in rats are germane at all to the human.

\section{CONCLUSION}

Rat milk leukocytes protect newborn rats from experimental bacterial necrotizing enterocolitis. These cells can also phagocytize and kill the bacteria in vitro. The bactericidal activity is not entirely intracellular.

The data do not establish the fact that the bactericidal activity of the leukocytes is the prime mechanism of production against enterocolitis in the rat. It is possible that some indirect influence of these leukocytes on the immune responses of the neonatal rat are key to the protection. No valid conclusions may be drawn from these animal studies that would automatically apply to man. Careful prospective human studies are required before any extrapolation may be made.

\section{REFERENCES AND NOTES}

1. Argyris, B. F.: Role of macrophage in immunological maturation. J. Exp. Med., 128: 467 (1968).

2. Barlow, B., Santulli, T. V., Heird, W. C., Pitt, J., Blanc, W. A., and Schullinger, J. N.: An experimental study of acute neonatal enterocolitisThe importance of hreast milk. J. Pediat. Surg., 9: 595 (1974).

3. Beer, A. E., Billingham, R. E., and Head, J.: Proceedings: The immunologic significance of the mammary gland. J. Invest. Dermatol., 63: 74 (1974).

4. Braun, W., and Lasky, L.: Antibody formation in newborn mice initiated through adult macrophages. Fed. Proc., 26: 648 (1967).

5. Bullen, J. J., Rogers, H. J., and Leigh, L.: Iron-binding proteins in milk and resistance to Escherichia coli infection in infants. Brit. Med. J., 1: 75 (1972).

6. Chwatt, B. L. J., and Gibson, F. D.: Transplacental passage of Plasmodium berghei and passive transfer of immunity in rats and mice. Roy. Soc. Trop. Med. Hyg., 50: 53 (1956).

7. Culbertson, J. T.: Natural transmission of immunity against Trypanosoma lewisi from mother rats to their offspring. J. Parasitol., 24: 82 (1938).

8. Halliday, R., and Kekwick, R. A.: Electrophoretic analysis of the sera of young rats. Proc. Roy. Soc. B., 153: 437 (1957).

9. Hanson, L. A., and Johansson, B. G.: Immunological studies of milk. In H. A. McKenzie: Milk Proteins: Chemistry and Molecular Biology, Vol. 1 (Academic Press, New York. 1970).

10. Kirkpatrick, C. H., Green, I., Rich, R. R., and Schade, A. L.: Inhibition of growth of Candida albicans by iron-unsaturated lactoferrin: Relation to host-defense mechanisms in chronic mucocutaneous candidiasis. J. Infect. Dis., 124: 544 (1971).

11. Klebanoff, S. J., Clem. W. H., and Luebke, R. G.: The peroxidase thiocyanate-hydrogen peroxide antimicrobial system. Biochim. Biophys. Acta, 117: $72(1966)$.

12. Leibovich, S. J., and Ross. R.: The role of the macrophage in wound repair. Amer. J. Pathol., 78: 71 (1975).

13. Michael, J. G.. Ringeback, R., and Hottenstein, S.: The antimicrobial activity of human colostral antibody in the newborn. J. Infect. Dis., 124: 448 (1971).

14. Miller, H. M.: Transmission to offspring of immunity against infection with metazoan (cestode) parasite. Proc. Soc. Exp. Biol. Med.. 29: 1124 (1932).

15. Miller, S. A., and Dymsza, H. A.: Artificial feeding of neonatal rats. Science, 517: $518(1963)$.

16. Murillo, G. J., and Goldman. A. S.: The cells of human colostrum. II Synthesis of 1 GA and beta 1 c. Pediat. Res.. 4: 75 (1970).

17. Pitt, J.: Unpublished observations.

18. Pitt, J., and Barlow, B.: Unpublished observations.

19. Simmons, S. R., and Karnovsky, M. L.: Iodinating ability of various leukocytes and their bactericidal activity. J. Exp. Med., 138: 63 (1973)

20. Stechschiute, D. J., and Austen, K. F.: Immunoglobulins of rat colostrum. J. Immunol., 104: 10562 (1970).

21. Stossel, T. P., Mason, R. J., and Smith, A. L..: Lipid peroxidation hy human hlood phagocytes. J. Clin. Invest., 54: 645 (1974).

22. Stuart, A. E., Biozzi, G., Stiffel, C., Halpern, B. N., and Mouton, D.: The stimulation and depression of reticuloendothelial phagocytic function by simple lipids. Brit. J. Exp. Pathol., 4l: 604 (1960).

23. Wood, B. W.: Phagocytosis with particular reference to encapsulated bacteria. Bacteriol. Rev.. 24: 9)(1960).

24. Difco Laboratories, Detroit, Mich.

25. Camm Research, Wayne, N. J.

26. Ross Laboratories, Columbus, Ohio.

27. Borden, Inc., Norfolk, Va.

28. Parke-Davis, Detroit, Mich.

29. Pharmacia, Piscataway, N. J.

30. Falcon Plastics, Oxnard. Calif.

31. Rotorack, Fisher Scientific. Springfield, N. J.

32. Medicath. Chesehorough Ponds, New York, N. Y.

33. This research was supported in part by NICHD grants HD 03993,08432 , and 09139, Ross Laboratories, and The Charles Edison Fund.

34. Requests for reprints should be addressed to: J. Pitt, M.D., Department of Pediatrics, Columbia College of Physicians and Surgeons, 630 W. 168 St., New York, N. Y. 10032 (USA).

35. Received for publication October 26, 1976

36. Accepted for publication January 14, 1977. 